Vol.45, Special n. : pp. 1-7, September 2002 ISSN 1516-8913 Printed in Brazil

BRAZILIAN ARCHIVES OF BIOLOGY AND TECHNOLOGY

AN INTERNATIONAL JOURNAL

\title{
Nuclear Medicine in Tropical Diseases
}

\author{
Francisco José Hossri Nogueira Braga* \\ Serviço de Medicina Nuclear; Centro Oncológico da Região de Araraquara; Rua Carlos Gomes, 2000; 14340-801; \\ Araraquara - SP - Brazil; fjbraga@dfm.ffclrp.usp.br
}

\begin{abstract}
Tropical diseases affect more people in the world than any other kind of disease, but scintigraphic data on that matter are not so frequent in the literature. Since the geographic regions where such diseases occur are normally very poor, scintillation cameras may not be available. We present a resumed summary of part of what has been done on this subject to-date. Leprosy affects circa 12 million people worldwide and has already been studied by means of the following scintigraphic exams: Gallium-67, 99mTc-MDP or HMDP, 99mTc-colloid or Dextran, $99 m T c-D T P A$ and $99 m$ Tc-WBC. Paracoccidiodomycosis is a deep mycosis and such cases may be evaluated by means of Gallium-67, bone scintigraphy, lymphoscintigraphy, hepato-billiary, bone marrow and liver / spleen scintigraphies. Mycetoma is bone and soft tissue mycosis and gallim-67 and bone studies are very useful in the evaluation of such cases. Tuberculosis is the most well studied tropical disease and dozens of radiopharmaceuticals and techniques were described to evaluate such patients. Jorge Lobo's disease is a rare mycosis that affects mainly indians from the Amazon region and gallium-67 was shown to accumulate in active disease. Neurocysticercosis is spread worldwide and brain SPECT (99mTc-ECD or 99mTc-HMPAO) is a very good tool for the functional evaluation of the disease. Patients suffering from Cutaneous and mucous leishmaniosis may benefit from Gallium67 scintigraphy. Chagas' disease may affect the heart and/or the digestive tract and several scintigraphic exams may be helpful in the evaluation of such cases (gated blood pool, heart perfusion tests, pharyngeal transit tests, gastric emptying tests, intestinal transit tests, hepato-billiary scintigraphy, among others). Scintigraphy should be more largely used in the functional evaluation of organs and systems of patients affected by topical diseases. It is a powerful tool to evaluate both the extent of disease and the efficacy of therapy.
\end{abstract}

Key words: Nuclear medicine, scintigraphy, tropical diseases, leprosy, paracoccidioidomycosis, blastomycosis, mucormycosis, tuberculosis, neurocysticercosis, cutaneous and mucous leishmaniasis, Chagas' disease

\section{INTRODUCTION}

\section{Leprosy}

Leprosy (or Hansen's disease) is a millenary chronic infectious granulomatous disease caused by Mycobacterium leprae, a bacillus that has a strong positive neurotropism (Bechelli 1975). The World Health Organisation estimates that more than 12 million people are affected by leprosy in the world. Skin is most frequently affected, but nearly all organs may be the siege of the disease. Scintigraphy is a technique that allows functional evaluation of organs and systems; it is complementary to common radiological techniques, which allow only anatomical evaluation. The nuclear technique can be used both to detect active leprosy in the skin and to evaluate different organs and systems affected by the disease.

\footnotetext{
* Author for correspondence
} 


\section{a) Gallium-67 scintigraphy}

Gallium-67 citrate scintigraphy ( 24 and $48 \mathrm{~h}$ after injection images, 300,000 counts per image) may be used to detect active multibacilary forms of Hansen's disease (Braga 1989a, Braga 1991, Mouratidis 1993). Typically, the finding is moderate and diffuse uptake of the radiopharmaceutical in the skin, producing a "skin outlining" sign. Particularly important in the face, which often has a large concentration of lepromas, the uptake of Gallium produces there a "beard sign" (Braga 1991). Several moderate, focal and irregular spots of uptake are seen with $99 \mathrm{mTc}$ HMPAO labelled white blood cells in cases of erythema nodosum leprosum (Peng 1998).

\section{b) $99 m T c-D T P A$ dynamic renal study}

Routine dynamic renal study (99mTc-DTPA, 750 $\mathrm{MBq}$ intravenously; arterial and sequential images) can detect impaired renal function, as delayed $\mathrm{T}^{1 / 2}$ of elimination of the radiopharmaceutical is seen before creatinine levels are abnormal (Braga 1996). Authors mention amyloidosis and glomerulonephritis, among others, as the main causes of affected renal function in leprosy (Bechelli 1975).

\section{c) $99 m T c-M D P$ or HMDP bone scintigraphy}

Bone leprosy may be considered as osteomyelitis and conventional three-phase bone scintigraphy (99mTc-MDP or HMDP, $750 \mathrm{MBq}$ intravenously; arterial, equilibrium and late images, $2 \mathrm{~h}$ after injection) is very sensitive to detect disease (Soni 1998). In addition, the exam is useful to detect active disease in cases of mutilation of extremities, which was very frequent in the past, but is still found. Mutilated extremities with active disease are seen as increased blood flow areas (in the arterial phase of the exam) and important and focal increased uptake of the tracer in the late phase. The nuclear examination seems to be superior to conventional X-ray studies to detect active leprosy in cases of mutilation (Braga 1999a).

\section{d) 99mTc-sulphur liver and spleen colloid scintigraphy}

Important splenomegaly is often seen in multibacillary leprosy and liver and spleen scintigraphy $(99 \mathrm{mTc}$ sulphur or tin colloid, 100
$\mathrm{MBq}$ intravenously, 500,000 count images obtained 15 minutes later) is very useful to evaluate the homogeneity of such organs (Braga 1996). Although further work is necessary, it is possible that inhomogeneous distribution of the tracer in liver and spleen may indicate active local disease.

\section{Paracoccidioidomycosis}

Paracoccidioidomycosis (also known as Blastomycosis) is a deep mycosis caused by Paracoccidioidis brasiliensis that affects nearly all organs and systems, the lungs being the most frequent ones. The determination of disease extent and the differentiation between active and inactive disease may not be an easy task and scintigraphy is very helpful in such situations. It is superior to conventional X-ray examinations (Giorgi 1987). The following nuclear exams have already been successfully tested to evaluate blastomycosis: Gallium-67, bone scintigraphy, bone marrow scintigraphy, hepato-billiary scintigraphy, liver and spleen scintigraphy and lymphoscintigraphy.

\section{a) Gallium-67 scintigraphy}

Conventional Gallium scintigraphy is a good tool both to detect active foci of paracoccidioidomycosis and to follow up therapy. The typical finding is diffuse and variable uptake of the tracer in the lungs and focal but also variable uptake in other anatomic al regions (bone, lymph nodes, liver and spleen). Conventional thorax X-ray examinations may not be able to separate active disease and fibrosis (Giorgi 1987). The interpretation of the abdominal area may be difficult in Gallium scintigraphy, mainly concerning lymph nodes. Specific exams (bone and liver-spleen scintigraphy and lymphoscintigraphy) may be of value (Braga 1988, Braga 1990, Braga 1992a, Shikanai-Yasuda 1992) after the Gallium evaluation.

\section{b) Bone scintigraphy}

The aspect of bone blastomycosis seen with diphosphonates is similar to the one of chronic osteomyelitis, with moderate / important abnormal uptake of the radiopharmaceutical in the affected bone (Even-Sapir 1993, Daniel 1993). The extent 
of bone disease is better evaluated by scintigraphy, as compared to conventional $\mathrm{X}$-ray studies.

\section{c) 99mTc-colloid or Dextran lymphoscintigraphy}

The exam is performed after the sub-cutaneous injection of $99 \mathrm{mTc}$-colloids or Dextran (370 $\mathrm{MBq})$. The place of injection will depend upon the chain to be evaluated. Normal lymph nodes do not take the tracers up and are not seen, but affected nodes are detected as important areas of uptake, following the path of the chain (Braga 1992a). For the evaluation of abdominal ganglia $2-3$ hours may be needed. Treatment is followed by the regression of the abnormalities.

\section{d) Liver and spleen scintigraphy}

Blastomycotic lesions in the liver and spleen produce heterogeneous distribution of the tracer in the organs, with clearly cold defects (Braga 1990). Treatment is followed by the regression of such abnormalities.

\section{e) Hepato-billiary scintigraphy (99mTc HIDAs)}

Hepato-billiary function may be evaluated by means of the 99mTc-HIDAs. Active blastomycosis in the liver leads to a slow rate of tracer uptake by the hepatocyte after injection. In moderate cases the gallbladder is lately and faintly seen but in severe cases neither the bladder not radioactivity in the intestines are seen (Braga 1998a). The lack of visualisation of the gallbladder may lead to an erroneous diagnosis of acute cholecystitis. Hepatic enzymes are frequently normal in the mentioned situation and the exam may be used for the early detection of liver dysfunction.

\section{Mucormycosis}

There is not a complete agreement among authors (Bechelli 1975) but many consider mucormycosis, Madura foot and mycetoma as synonyms. It is a bone and soft tissue fungal disease caused by several etiological agents, Madurella grisea being one of the most frequent ones. It affects mainly the feet producing important enlargement of the extremity. Gallium-67 and three-phase bone scintigraphy have already been used to study the disease (Braga 1989b, Braga 1993, Ganguli 1999).

\section{a) Gallium-67}

Conventional Gallium-67 scintigraphy showed that very important accumulation of the tracer is seen in active lesions, both in bone and in soft tissues, and that treatment leads to normalisation. Interestingly, kidneys also concentrate the radioactive material abnormally, although no explanation could be found for that finding to date (Braga 1993).

\section{b) Bone scintigraphy}

The pattern of three-phase bone scintigraphy in the disease is similar to the one seen in accute osteomyelitis associated to cellulitis, even in cases under specific treatment. This finding differs from the ones described in bone blastomycosis and in bone leprosy, where even untreated disease appears as chronic osteomyelitis. Large areas of abnormal uptake of diphosphonates are seen, with increase of foot volume (Braga 1993, Ganguli 1999). Much interestingly, also in this exam kidneys concentrate the radioactive material abnormally and one of the differential diagnosis to be thought of is diabetes.

\section{Tuberculosis}

Tuberculosis is a granulomatous disease caused by several Mycobacteria, Mycobacterium tuberculosis being the most frequent one, at least in immune-competent patients. It is perhaps the most extensively studied infectious disease, probably due to its dissemination throughout the world. Tuberculosis may affect nearly all organs and systems, but the lungs are far the most frequent site of disease. The list of Nuclear Medicine techniques described as useful is enormous.

Briefly, a résumé of the nuclear techniques that may be used include:

- plannar and tomographic Gallium-67 (Walsh, 1985; Grieff, 1991; Gomez, 1996; Lai, 1997, Utsonomiya, 1997; Del Val Gomez, 1998; Montero, 1998);

- 99mTc-Tetrofosmin (Degirmenci, 1998);

- Thallium-201(Gomez, 1996; Utsonomiya, 1997);

- 99mTc-MIBI (Oncel, 1996); 
- 99mTc-macro-aggregate of albumin and 99mTc-DTPA (Palamarcuk, 1988; Chanoine, 1988);

- 99mTc-labelled antibody fragment against Mycobacterium bovis bacillus CailmetteGuérin (Lee, 1992);

- labelled somatostatin analogues (Vanhagen, 1994); and

- 99mTc-gluco-heptonate (Braga, 1998b).

Most of them concern lung tuberculosis but many mention the evaluation of other sites affected by the disease. The main uses of the technique are to detect and evaluate the extent of disease and differentiate active from inactive status.

\section{Cheloidean Paracoccidiodo-Mycosis (Jorge Lobo's Disease)}

Chelloidean Paracoccidioidomycosis (also known as Jorge Lobo's Disease) is a rare superficial mycosis caused by Paraccocidioidis loboii. It affects mainly indians from the Amazon region. It was shown that Gallium-67 scintigraphy is useful to detect active disease (Braga, 1992b) and the scintigraphic aspect seen in the exam is a focal and moderate abnormal uptake of gallium.

\section{Neurocysicercosis}

Cysticercosis of the brain is a parasitic infectious disease caused by Taenia solium eggs that set in the Central Nervous System and produce cysts within the brain parenchyma, although other forms of the disease also exist (ventricular, meningeal, etc). Its incidence is increasing both in the developing and the developed world and WHO estimates that disease affects around 50 million people. Clinical manifestation of disease vari es from no symptoms to epilepsy, increased intra cranial pressure, arachnoiditis and dementia. It is the most common cause of epilepsy in Latin America. 99mTc-ECD and 99mTc-HMPAO brain SPECT can be used in the functional evaluation of the disease (Braga, 1995). Two SPECT patterns are noted: a) several areas of focally reduced uptake, resulting from coalescent and big lesions and large destruction of brain tissue; b) diffuse atrophy with reduction of the tracer uptake, associated with ventricle dilatation, corresponding to the cases where ventricular neurocysticercosis was important. Interestingly, diffuse hypoperfusion indicating atrophy may be seen in cases of massive parenchymal infection, with much less prominent CT signs of atrophy (Braga, 1998c; Braga, 1999b).

\section{Cutaneous / Mucous Leishmaniasis}

This form of leishmaniosis is caused by Leishmania brasiliensis and transmitted to man by some insects from the Phlebotominae family. It is a worldwide spread disease. Gallium-67 scintigraphy was shown to accumulate in anatomical areas affected by active disease and the aspect seen is that of moderate and focal uptake of the radiopharmaceutical (Braga, 1992c).

\section{Chagas' Disease}

Chagas' disease is caused by Trypanosoma cruzi. Disease destroys small nerves in mus cles. Clinical manifestation varies according to the affected organs / regions. The chronic cardiac form of Chagas presents with cardiac insufficiency and severe heart dilatation. Coronary artery disease may occur. Chagas is responsible for the smallest LV ejection fractions described in the literature (as small as $6 \%$ ). Chronic gastrointestinal forms of Chagas lead to dysmotility and megas (mega colon and mega-oesophagus being the most frequent ones). The disease is one of the main causes of sudden death of cardiac origin in endemic areas.

\section{a) 99mTc Red blood cells (gated blood pool)}

Impaired LV ejection fraction, amplitude and phase contraction are detected by gated blood pool in this clinical situation. Apex aneurysm rupture is the main cause of death in Chagas and it can be easily detected by scintigraphy (Meneguetti, 1984). The conventional radiological approach to this situation is very invasive.

\section{b) Heart Perfusion examinations}

Both Thallium-201 (Marin-Neto 1992) and microspheres (Marin-Neto, 1995) may be used to detect abnormal perfusion of the left ventricle, although microspheres must be injected directly into the coronary. Right ventricle affection may be prominent (Marin-Neto, 1988). 


\section{c) Gastrointestinal dysmotility evaluation}

Dysphagia (Souza, 1998), abnormal intestinal transit (Troncon, 1993), abnormal gastric emptying (Troncon, 1992; Troncon, 1993) and duodeno-gastric reflux (Troncon, 1986) may be easily detected and quantified by means of nuclear techniques. Several radiotracers (solid, liquid an d semi-liquid ones) may be used. All other techniques used to date in such cases are invasive. In conclusion, we believe that scintigraphic techniques should be more largely used in the evaluation of organs and systems of patients affected by tropical diseases, as it provides information clinicians cannot obtain from anatomical methods.

\section{RESUMO}

Doenças tropicais afetam mais pessoas no mundo do que outros tipos de doenças, mas na literatura estudos cintigráficos sobre este assunto não são tão freqüentes já que as câmaras de cintilação podem não estar disponíveis nas regiões geográficas onde essas doenças ocorrem que são, normalmente, pobres. Nesse trabalho apresentamos um resumo do que tem sido feito nesta área até o momento. A Lepra (Hanseníase) afeta cerca de 12 milhões de pessoas no mundo todo e tem sido estudada pelos seguintes exames cintigráficos: Gálio-67, MDPTc-99m ou HMDP, colóide ou Dextran marcado com Tc-99m, DTPA-Tc-99m e hemácias marcadas com Tc-99m. Paracoccidiodomicose é uma micose profunda e tais casos podem ser avaliados com Gálio-67, cintigrafia óssea, linfocintigrafia, cintigrafia hepato biliar, medular e de fígado/baço. Micetoma é uma micose de osso e tecido mole e o gálio-67 e a cintigráfia óssea são úteis na avaliação de tais casos. A tuberculose é a doença tropical mais estudada e uma dúzia de radiofármacos e técnicas têm sido descritas para avaliar os pacientes. A Doença de Jorge Lobo é uma micose rara que afeta principalmente os índios da região amazônica e o gálio-67 mostrou acumular-se na doença ativa. A neurocisticercose está difundida no mundo inteiro e imagens cerebrais em SPECT (ECD-Tc-99m e HMPAO-Tc-99m) constituem ferramentas para a avaliação funcional da doença. Pacientes que sofrem de leishmaniose cutânea e visceral podem ser estudados através de cintigrafias com Gálio-67. A Doença de Chagas pode afetar o coração e/ou o trato digestivo e, alguns exames de cintigrafias podem ser úteis na avaliação de tais casos (pool sanguíneo, testes de perfusão cardíaca, de trânsito faringeal, de esvaziamento gástrico,de trânsito intestinal, cintigrafias hepato biliares, dentre outros). As cintigrafias deveriam ser mais largamente utilizadas para a avaliação funcional de órgãos e sistemas de pacientes afetados por doenças tropicais. È uma ferramenta poderosa para a avaliação da extensão da doença e da eficácia da terapia.

\section{REFERENCES}

Bechelli, L. M. and Curvan, L. (1975), Compêndio de Dermatologia. São Paulo: Funconiz..

Braga, F. J. H. N.; Segurado, A.A. C.; Pinto, W. P.; Shikanai-Yasuda, M. A. and Camargo, E. E. (1988), Four radioisotopic studies in paracoccidioidomycosis: preliminary results. In- Abstract book International Congress for Infectious Diseases. V Congresso da Sociedade Brasileira de Infectologia. Rio de Janeiro, International Society for Infectious Diseases. pp. 87.

Braga, F. J. H. N.; Rivitti, M. C. M.; Abreu, P. R.; Tedesco Marchesi, L. C. M.; Camargo, E. E. and Sampaio, S. A. P. (1989a), Cintilografia de corpo inteiro com Gálio-67 em Hanseníase (resultados preliminares). Rev. Inst. Med. Trop. S. Paulo, 31, 85.

Braga, F. J. H. N.; Rivitti, M. C. M.; Abreu, S. M.; Belda Jr., W. and Cucê, L. C. (1989b), Double scintigraphic evaluation with Ga-67 and bone study in mycetomas: a possibility of therapy checking. Eur. J. Nucl. Med., 15, 555.

Braga, F. J. H. N.; Abreu, PR; Camargo, EE; ShikanaiYasuda, MA; Segurado, AAC; Gambini, DJ; Barritault, L. (1990), Four radioisotopic studies in paracoccidioidomycosis. Eur. J. Nucl. Med., 15, 494.

Braga, F. J. H. N.; Araújo, E. B.; Rivitti, M. C. M.; Tedesco Marchesi, L. C. M; Camargo, E. E.; Bouladour, H.and Galle, P. (1991), Gallium-67 scintigraphy in Hansen's disease. Eur. J. Nucl. Med., 18, 866-869.

Braga, F. J. H. N.; Segurado, A. A. C.; ShikanaiYasuda, M. A.; Camargo, E. E.; Iazigi, N.; Gambini, D. J. and Barritault, L. (1992a), La paracoccidioidomycose évaluée par quatre études isotopiques. Bull. Soc. Path. Exo. Inst. Pasteur, 85, 115-117.

Braga, F. J. H. N.; Abreu, P. R.; Rivitti, M. C. M.; Tedesco Marchesi, L. C. M. ; Gambini, D. J.; Barritault, L. (1992b), La paracoccidioidomycose chéloïde étudiée avec le gallium. Bull. Soc. Path. Exo. Inst. Pasteur, 85, 118-119. 
Braga, F. J. H. N.; Rivitti, M. C. M.; Tedesco Marchesi, L. C. M.; Camargo, E. E.; Gambini, D. J.; Barritault, L. ( 1992c), Contribution au début de l'étude de deux maladies infectieuses à l'aide de la scintigraphie au gallium-67: la lèpre et al leishmaniose cutanée et muqueuese. Bull. Soc. Path. Exo. Inst. Pasteur, 85, 53-57.

Braga, F. J. H. N.; Araújo, E. B.; Camargo, E. E.; Rivitti, M. C. M. and Cucê, L. C. (1993), Scintigraphic evaluation of mycetoma. Nucl. Med. Comm., 14, 814-818.

Braga, F. J. H. N.; Takayanagui, O.; Santos, A. C. and Moura, A. C. (1995), HMPAO SPECT in neurocysticercosis: perliminary results. Eur. J. Nucl. Med., 22, 871.

Braga, F. J. H. N.; Foss, N. T.; Merchior Jr., E. and Tfouni, E. (1996), Nuclear Medicine in leprosy. Eur. J. Nucl. Med., 23, 1182.

Braga, F. J. H. N.; Machado, A. A. and Iazigi, N. (1998a), 99mTc-DISIDA scintigraphy to evaluate liver function in blastomycosis patients. In- Abstract book 2nd European Congress on Tropical Medicine. Liverpool, Setembro de 1998. Liverpool, Federation of European Societies for Tropical Medicine and International Health. pp. 69.

Braga, F. J. H. N.; Arbex, M. A.; Haddad, J. and Bonini, E. H. (1998b), 99mTc-gluco-heptonate scintigraphy in lung tuberculosis patients: initial results. Eur. J. Nucl. Med., 25, 1125.

Braga, F. J. H. N.; Takayanagui, O.; Santos, A. C.; Iazigi, N. and Trad, C. S. (1998c), Brain SPECT in neurocysticercosis patients. In- Abstract book 2nd European Congress on Tropical Medicine. Liverpool, Setembro de 1998. Liverpool, Federation of European Societies for Tropical Medicine and International Health. pp. 32.

Braga, F. J. H. N.; Foss, N. T.; Ferriolli, E.; Miranda, J. R. A. and Moraes, R. (1999a), The use of bone scintigraphy to detect active Hansen's disease in mutilated patients. Eur. J. Nucl. Med.

Braga, F. J. H. N.; Miranda, J. R. A.; Santos, A. C.; Takayanagui, O. M.; Ferrioli, E.; Moraes, R.; Agapejev, S. and Alves, A. (1999b), ECD SPECT in neurocysticercosis. Neurorradiol, [sent for publication].

Chanoine, J. P. ; Toppet, M.; Dab, I.; Toppet, V.; Tondeur, M.; Ham, H. and Piepsz, A. (1988), Unusual ventilation-perfusion patterns in primary lung tuberculosis. Pediatr. Pulm., 5, 51-54.

Daniel, B. L.; Crabbers, J. P. and Grieters, L. (1993), Bone scintigraphy in blastomycotic osteomyelitis. Clin. Nucl. Med., 18, 203-207.

Del Val Gómez Martínez, M.; Gallardo, F. G.; March, J. and Laguna, F. (1998), Gallium-67 (Ga-67) scintigraphy in tuberculosis and Mycobacterium avium-M. intracellulare infections in patients with HIV infections. Med. Clin. (Barc), 110, 570-573.
Degirmenci, B.; Kilinc, O.; Cirak, K. A.; Capa, G.; Akpinar, O.; Halilcolar, H.; Durak, H.; Akkoclu, A.; Derebek, E. and Ucan, E. S. (1998), Technetium$99 \mathrm{~m}$-tetrofosmin scintigraphy in pulmonary tuberculosis. J. Nucl. Med., 39, 2116-2120.

Even-Sapir, E.; Martin, R. H. and Marrie, T. J. (1993), Gallium-67-citrate and bone scintigraphy in disseminated North American blastomycosis. J. Nucl. Med., 34, 458-461.

Ganguli, S. N. and Hershkop, M. (1999), Bone scintigraphy of Madura foot. Clin. Nucl. Med., 24, 284-285.

Giorgi, M. C. P.; Camargo, E. E.; Pinto, W. P. and DelNegro, G. (1987), Gallium-67 imaging in the diagnosis of blastomycosis. Eur. J. Nucl. Med., 13, 300-304.

Gomez, M. V.; Gallardo, F. G.; Cobo, J. and Babe, J. (1996), Identification of AIDS-related tuberculosis with concordant gallium-67 and three-hour delayed thallium-201scintigraphy. Eur. J. Nucl. Med., 23, $852-854$.

Grieff, M. and Lisbona, R. (1991), Detection of miliary tuberculosis by Ga-67 scintigraphy. Clin. Nucl. Med., 16, 910-912.

Lai, F. M.; Liam, C. K.; Paramsothy, M. and George, J. (1997), The role of 67-gallium scintigraphy and high resolution computed tomography as predictors of disease activity in sputum smear-negative pulmonary tuberculosis. Int. J. Tuberc. Lung. Dis., 1, 563-569.

Lee, J. D.; Shin, K. H.; Cho, S. N.; Shin, J. S.; Lee, M. G.; Yang, W. I.; Park, C. Y.; Yoo, H. S.; Lee, J. T. and Awh, O. D. (1992), Immunoscintigraphy in the detection of tuberculosis with radiolabelled antibody fragment against Mycobacterium bovis bacillus Calmette-Guérin: a preliminary study in a rabbit model. Eur. J. Nucl. Med., 19, 1011-1015.

Marin-Neto, J. A.; Marzullo, P. and Souza, A. C. S. (1988), Radionuclide angiographic evidence for early predominant right ventricular involvement in patients with Chagas-Disease. Can. J. Cardiol., 5, 231-236.

Marin-Neto, J. A.; Marzullo, P. and Marcassa, C. (1992), Miocardial perfusion abnormalities in chronic Chagas-Disease as detected by Tl-201 scintigraphy. Am. J. Cardiol., 69, 780-784.

Marin-Neto, J. A.; Marzullo, P. and Ayres-Neto, E. (1995), Miocardial perfusion disturbances detected by 99mTc-microspheres in Chagas patients with angiographically normal coronary arteries. Circulation, 92, 2250-2250.

Menegueti, J. C.; Neto, J. E. and Hironaka, F. (1984), The importance of exercise gated blood pool imaging in Chagas-Disease. J. Nucl. Med., 25, P81-P81.

Mouratidis, B. and Lomas, F. E. (1993), Gallium-67 scintigraphy in borderline lepromatous leprosy. Australas Radiol., 37, 270-271. 
Montero, A.; Carril, J. M.; Quirce, R.; Blanco, I.; Uriarte, I.; Bernal, J. M. and Hernández, A. (1998), Contribution of planar scintigraphy and SPECT with Ga-67 in the diagnosis of infectious complications after median sternotomy. Rev. Esp. Med. Nucl., 17, 331-337.

Onsel, C.; Sonmezoglu, K.; Camsari, G.; Atay, S.; Cetin, S.; Erdil, Y. T.; Uslu, I.; Uzun, A.; Kanmaz, B. and Sayman, H. B. (1996), Technetium-99m-MIBI scintigraphy in pulmonary tuberculosis. J. Nucl. Med., 37, 233-238.

Palamarcuk, V. P.; Vlasova, M. M.; Amosov, V. I. and Lapekin, S. V. (1988), Perfusion scintigraphy and xray diagnosis of pulmonary tuberculosis. Radiobiol. Radiother. (Berl), 29, 481-488.

Peng, N. J.; Wang, J. H.; Hsieh, S. P.; Jao, G. H.; Tsay, D. G. and Liu R. S. (1998), Ga-67 and Tc-99m HMPAO labeled WBC imaging in erythema nodosum leprosum reaction of leprosy. Clin. Nucl. Med., 23, 248-250.

Shikanai-Yasuda, M. A.; Guerrini, R.; Watanabe, T.; Higaki, Y.; Segurado, A. A. C.; Bueno, J. P.; Bernard, G.; Gryschek, R. C. B.; Braga, F. J. H. N.; Amato Neto, V. and Magalhães, A. E. A. (1992), Lung involvement in paracoccidioidomycosis. Gallium-67 imaging and computerized axial tomography. Rev. Arg. Micol., 15, 68.

Soni, A.; Mittal, B. R.; Kaur, I.; Sharma, V. K.; Pathak, C. M. and Kumar B. (1998), Bone scintigraphy in leprosy. Int. J. Leprosy, 66, 483-484.
Souza, M. A. N.; Dantas, R. O.; Oliveira, R. B. and Braga, F. J. H. N. (1998), Scintigraphic study of oropharyngeal swallowing dynamics in Chagas' disease. Dig. Dis. Scien., 43, 1595.

Troncon, L. E. A.; Rezende, J. and Iazigi, N. (1986), Duodenograstric reflux in chronic Chagas-Disease. Braz. J. Med. Biol. Res., 19, A557-A557.

Troncon, L. E. A. and Iazigi, N. (1992), Scintigraphic study of the gastrointestinal transit of a liquid meal in patients with Chagas-Disease. Braz. J. Med. Biol. Res., 25, 45-148.

Troncon, L. E. A.; Oliveira, R. B. and Romanello, L. M. F. (1993), Abnormal progression of a liquid meal through the stomach and small intestine in patients with Chagas-Disease. Dig. Dis. Sci., 38, 1511-1517.

Utsunomiya, K.; Narabayashi, I.; Nishigaki, H.; Tsujimoto, K.; Kariyone, S. and Ohnishi, S. (1997), Clinical significance of thallium-201 and gallium-67 scintigraphy in pulmonary tuberculosis. Eur. J. Nucl. Med., 24, 252-257.

Vanhagen, P. M.; Krenning, E. P.; Reubi, J. C.; Kwekkeboom, D. J.; Bakker, W. H.; Mulder, A. H.; Laissue, I.; Hoogstede, H.C. and Lamberts, S. W. (1994), Somatostatin analogue scintigraphy in granulomatous diseases. Eur. J. Nucl. Med., 21, 497502.

Walsh, T. J.; Bekerman, C.; Chausow, A. and Szidon, P. (1985), The value of gallium-67 scanning in pulmonary tuberculosis. Am. Rev. Respir. Dis., 132, 746-747. 